\title{
Enhanced Emergence and Seedling Vigor in shrunken-2 Sweet Corn via Seed Disinfection and Solid Matrix Priming
}

\author{
Carlos A. Parera and Daniel J. Cantliffe \\ Vegetable Crops Department, University of Florida, Gainesville, FL 32611 \\ Additional index words. Zea mays, seed priming, seed emergence, sodium hypochlorite
}

\begin{abstract}
Presowing seed treatments were devised to improve emergence and crop uniformity of two sweet corn (Zea mays L.) cultivars ['Crisp N' Sweet 711' (CNS-711) and 'How Sweet It Is' (HSII)] that carry shrunken-2 (sh2) mutant endosperm. The treatments included a fungicide combination, sodium hypochlorite (SH), solid matrix priming (SMP), and SMP combined with SH during treatment (SMPSH). Seed germination was tested in a laboratory cold test. Emergence percentage, emergence rate index (ERI), and seedling dry weight were calculated from field trials. CNS711, in the cold test and field trials, had a higher germination rate, ERI, final emergence, and seedling dry weight than HSII. In both cultivars, SMPSH significantly improved germination in the cold test and final emergence and ERI in the field trials for HSII compared to nontreated seeds. There was no significant difference between the fungicide and SMPSH treatments regardless of cultivar. These results suggest that the combination of SMP and disinfection with SH can be an alternative seed treatment to fungicides to improve uniformity and stand establishment in sh2 sweet corns.
\end{abstract}

The poor seedling emergence in sh2 sweet corn cultivars has been attributed to low seed vigor (Styer and Cantliffe, 1983), high susceptibility to seed and soil-borne diseases (Berger and Wolf, 1974), and imbibitional damage (Parera and Cantliffe, 1991). Fungicide seed treatments have been reported to improve stand establishment and uniformity in supersweet corn cultivars (Cantliffe et al., 1975; Parera and Cantliffe, 1990).

Seed priming is used to increase germination rate, improve stand establishment, uniformity, and increase yield (Khan et al., 1980). Seed priming consists of imbibing seeds in an osmotic solution that allows seeds to imbibe water and go through the initial germination stages, but prevents radicle protrusion through the seedcoat (Cantliffe, 1981). Priming treatments have been reported as successful presowing treatments for many species (Bradford, 1986). Priming corn seed has yielded variable results. The emergence rate of corn germinated at low temperatures was improved by priming in a polyethylene glycol (PEG) solution (Bodsworth and Bewley, 1981). Seeds of sugary (su) and $s h 2$ sweet corn genotypes primed with PEG 8000 had lower field emergence than nontreated seeds (Bennett and Waters, 1987). Also, the aeration of the solution, the large volume of solution needed per seed, and the large amount of seeds required for commercial use has restricted osmotic priming for largeseeded species.

SPM is a priming method wherein seeds are moistened for a given time at constant temperature in an organic or inorganic solid matrix carrier to which water has been added (Harman and Taylor, 1988). The SMP uses the osmotic and physical characteristics of the solid carrier to restrict water absorption (Kubik et al., 1989). Early results with SMP on sh2 sweet corn were not always favorable. Rate of emergence and stand uniformity of $s h 2$ sweet corn sown in the field were not improved by SMP compared to nonprimed seeds (Cantliffe and Bieniek, 1988). Seedling emergence was enhanced by SMP in 'Jubilee' sweet

Received for publication 3 Sept. 1991. Accepted for publication 2 Dec. 1991. Univ. of Florida Agricultural Experimental Station Journal Series no. R01761. The cost of publishing this paper was defrayed in part by the payment of page charges. Under postal regulations, this paper therefore must be hereby marked advertisement solely to indicate this fact. corn, but was reduced in 'Florida Staysweet' compared to nontreated seeds (Harman et al., 1989).

The objective of this study was to develop a SMP treatment that would consistently improve emergence rate and total emergence of sh2 sweet corn cultivars under varying field conditions. To effectively prime $s h 2$ sweet corn, SMP has to control seedborne pathogens.

\section{Materials and Methods}

Plant materials. Seeds of two sh2 sweet corn cultivars, yellow-kernel CNS-711 and white-kernel HSII (Crookham Seed Co., Caldwell, Idaho), were used in this study.

Seed treatments. Surface disinfection was accomplished by soaking 200 seeds for $15 \mathrm{~min}$ in a 0.0596 solution (v/v) of SH. SMP consisted of placing $3 \mathrm{~g}$ of seed, $6 \mathrm{~g}$ of calcined clay, and $2.5 \mathrm{ml}$ (for HSII) or $2 \mathrm{ml}$ (for CNS-711) of distilled water in a closed container continuously rotated at $5 \mathrm{C}$ for $6 \mathrm{H}$, then transferring the sample to $25 \mathrm{C}$ and rotating it for $24 \mathrm{~h}$. After $30 \mathrm{~h}$ of incubation, $2 \mathrm{ml}$ (HSII) or $1.5 \mathrm{ml}$ (CNS-711) of water (SMP) or SH solution $(0.059 \%)$ (SMPSH) was added and seeds were incubated an additional $15 \mathrm{~h}$ (Parera and Cantliffe, 1991). The fungicide combination seed treatment consisted of soaking 200 $\mathrm{g}$ of seed for $2 \mathrm{~min}$ in 1 liter of solution of (1-(2-(2,4-dichlorophenyl)-2-(2-propenyloxy)ethyl)-1H imidazole) (imazalil) at $0.653 \mathrm{ml} / \mathrm{kg}$ seed, N-[(trichloromethyl)thio]-4-cyclohexene-1 ,2dicarboximide (captan) at $1.958 \mathrm{ml} / \mathrm{kg}$ seed, $\mathrm{N}$-(2,6 -dimethylphenyl)-N-(methoxyacetyl) alanine methyl ester (apron) at 0.488 $\mathrm{ml} / \mathrm{kg}$ seed, and tetramethylthiuram disulfide (thiram) at 3.264 $\mathrm{ml} / \mathrm{kg}$ seed (Parera and Cantliffe, 1990). After treatment, the seeds were dried back to their initial moisture content $(6 \%)$ in an incubator at $25 \pm 1 \mathrm{C}$ and $45 \%$ relative humidity $(\mathrm{RH})$. The seeds were stored at 10C and 45\% RH before and after treatment.

Cold germination test. Twenty seeds were sown in a plastic box $(18.7 \times 12.5 \times 9 \mathrm{~cm})$ on top of $2.5 \mathrm{~cm}$ of soil (Arredondo fine sand, loamy, silaceous, hyperthermic Grossarenic Palen-

Abbreviations: CNS-711, 'Crisp N' Sweet 711'; ERI, emergence rate index; HSII, 'How Sweet It Is'; SH, sodium hypochlorite; SMP, solid matrix priming. 
Table 1. Effect of seed treatments on germination of two sh2 sweet corn cultivars in a cold germination test.

\begin{tabular}{lcc}
\hline \hline & \multicolumn{2}{c}{ Cultivar } \\
\cline { 2 - 3 } Seed treatment & HSII & CNS-711 \\
\cline { 2 - 3 } \cline { 2 - 3 } SMPSH & 33 & Germination (\%) \\
SMP & 2 & 46 \\
SH & 0 & 13 \\
Fungicide (F) & 20 & 2 \\
Control (C) & 4 & 57 \\
& Orthogonal contrast & 31 \\
SMPSH vs. C & $* *$ & $*$ \\
SMP vs. SH & NS & $* *$ \\
SMPSH.vs. SMP & $* *$ & $* *$ \\
SMPSH vs. F & NS & NS \\
\hline NS & &
\end{tabular}

${ }^{\mathrm{NS}}, *, * *$ Nonsignificant or significant at $P=0.05$ or 0.01 , respectively.

Table 2. Effect of seed treatments on ERI, emergence percentage, and dry weight (DW) of HSII sweet corn cultivars in a field experiment planted in 26 Oct. 1989 at Gainesville, Fla.

\begin{tabular}{lccc}
\hline \hline & \multicolumn{2}{c}{ HSII } \\
\cline { 2 - 4 } Seed treatment & ERI & Emergence (\%) & DW $^{\mathbf{2}}(\mathrm{mg})$ \\
\hline SMPSH & 76 & 63 & 71 \\
SMP & 70 & 50 & 69 \\
SH & 30 & 27 & 55 \\
Fungicide (F) & 79 & 74 & 73 \\
Control (C) & 38 & 44 & 32 \\
& Orthogonal contrast & \\
SMPSH vs. C & $* *$ & $* *$ & $*$ \\
SMP vs. SH & $* *$ & $* *$ & NS \\
SMPSH vs. SMP & NS & NS & NS \\
SMPSH vs. F & NS & NS & NS \\
\hline
\end{tabular}

${ }^{2}$ Values are means of 20 plants 19 days after sowing.

, *, ** Nonsignificant or significant at $P=0.05$ or 0.01 , respectively.

undult) taken from a field where corn was grown continuously for 2 years. The soil was compacted and another $2.5 \mathrm{~cm}$ of soil was placed on top of the seeds. The soil was adjusted to 70'\% of its water-holding capacity. The containers were sealed and incubated at $10 \mathrm{C}$ for 7 days, then transferred to $25 \mathrm{C}$ for 4 days. Total germination percentage was calculated. Seedlings with leaves $2 \mathrm{~mm}$ in length above the soil were considered germinated.

Field studies. Field plots were established on 26 Ott. 1989 and 7 Mar., 27 Apr., and 8 Nov. 1990 at the Inst. of Food and Agricultural Sciences, Horticultural Unit, Gainesville, Fla., on an Arredondo fine sand soil. The plots were $7.60 \mathrm{~m}$ long on beds $1.22 \mathrm{~m}$ apart, with each bed $0.70 \mathrm{~m}$ wide and $0.20 \mathrm{~m}$ in height. Two seeds were sown $4 \mathrm{~cm}$ deep, every $30 \mathrm{~cm}$ in each plot (50 seeds/plot). Overhead sprinkler irrigation was applied as needed. ERI (Shmueli and Goldberg, 1971) and percent emergence were calculated. Five seedlings were cut at the soil level 22 days after sowing (DAS), weighed, and then dried at $75 \mathrm{C}$ for $72 \mathrm{~h}$ and reweighed. In the March and April sowings, the central $6 \mathrm{~m}$ of each plot were harvested. The ears were classified according to U.S. Dept. of Agriculture (1954) quality standards, then counted and weighed. Daily maximum and minimum soil temperatures at the $5-\mathrm{cm}$ depth were recorded for each planting.

Statistical analyses. The experiments were conducted as a randomized complete-block design, with treatments replicated four times. Percent emergence data were analyzed after square root arcsin transformations. Main effects of treatments were partitioned into orthogonal contrasts.

\section{Results and Discussion}

Since the interactions of treatment $\times$ cultivar and treatment $x$ sowing date were significant, main effects were partitioned and analyzed for each cultivar and sowing time. Only $4 \%$ of the nontreated HSII and 31\% of CNS-711 seeds germinated in a cold test experiment (Table 1). The SMPSH treatment significantly improved germination in both cultivars compared to nontreated seeds. In both cultivars, the germination of seed treated with fungicide did not significantly differ from that of SMPSHtreated seeds.

The cultivar CNS-711 had earlier seedling emergence (higher ERI) and higher emergence percentage and seedling vigor than HSII in the field test in Fall 1989 (Table 2). The seed treatments did not significantly improve the emergence percentage (range $81 \%$ to $94 \%$ ) or seedling vigor (ranges: ERI, 105-122; dry

Table 3. Effect of seed treatments on ERI, emergence percentage, and dry weight (DW) of two sh2 sweet corn cultivars in a field experiment planted 7 Mar. 1990 at Gainesville, Fla.

\begin{tabular}{|c|c|c|c|c|c|c|}
\hline \multirow[b]{3}{*}{ Seed treatment } & \multicolumn{6}{|c|}{ Cultivar } \\
\hline & \multicolumn{3}{|c|}{ HSII } & \multicolumn{3}{|c|}{ CNS-711 } \\
\hline & ERI & $\begin{array}{c}\text { Emergence } \\
(\%)\end{array}$ & $\begin{array}{l}D W^{z} \\
(\mu g)\end{array}$ & ERI & $\begin{array}{c}\text { Emergence } \\
(\%)\end{array}$ & $\begin{array}{l}\mathrm{DW} \\
(\mathrm{mg})\end{array}$ \\
\hline SMPSH & 217 & 66 & 2240 & 370 & 98 & 1117 \\
\hline SMP & 100 & 34 & 645 & 343 & 93 & 1110 \\
\hline SH & 118 & 42 & 715 & 364 & 93 & 1475 \\
\hline Fungicide (F) & 275 & 80 & 1125 & 386 & 95 & 1115 \\
\hline Control (C) & 124 & 42 & 955 & 323 & 91 & 1136 \\
\hline \multicolumn{7}{|c|}{ Orthogonal contrast } \\
\hline SMPSH vs. C & $* *$ & $* *$ & NS & $* *$ & NS & NS \\
\hline SMP vs. SH & NS & NS & NS & NS & NS & NS \\
\hline SMPSH vs. SMP & $* *$ & $* *$ & NS & NS & NS & NS \\
\hline SMPSH vs. F & NS & NS & NS & NS & NS & NS \\
\hline
\end{tabular}

${ }^{2}$ Values are means of 20 plants 27 days after sowing.

Ns $, *, * *$ Nonsignificant or significant at $P=0.05$ or 0.01 , respectively. 
Table 4. Effect of seed treatments on ERI, emergence percentage, and dry weight (DW) of two $s h 2$ sweet corn cultivars in a field experiment planted 23 Apr. 1990 at Gainesville, Fla.

\begin{tabular}{|c|c|c|c|c|c|c|}
\hline \multirow[b]{3}{*}{ Seed treatment } & \multicolumn{6}{|c|}{ Cultivar } \\
\hline & \multicolumn{3}{|c|}{ HSII } & \multicolumn{3}{|c|}{ CNS-711 } \\
\hline & ERI & $\begin{array}{c}\text { Emergence } \\
(\%)\end{array}$ & $\begin{array}{l}\mathrm{DW}^{\mathrm{z}} \\
(\mathrm{mg})\end{array}$ & ERI & $\begin{array}{c}\text { Emergence } \\
(\%)\end{array}$ & $\begin{array}{l}\mathrm{DW} \\
(\mathrm{mg})\end{array}$ \\
\hline SMPSH & 145 & 50 & 1327 & 230 & 83 & 2403 \\
\hline SMP & 98 & 32 & 1550 & 208 & 79 & 2480 \\
\hline SH & 76 & 32 & 1300 & 187 & 72 & 2073 \\
\hline Fungicide (F) & 132 & 58 & 668 & 192 & 79 & 2120 \\
\hline Control (C) & 56 & 22 & 393 & 160 & 66 & 1901 \\
\hline \multicolumn{7}{|c|}{ Orthogonal contrast } \\
\hline SMPSH vs. C & $* *$ & ** & $* *$ & $* *$ & NS & NS \\
\hline SMP vs. SH & NS & NS & NS & NS & NS & NS \\
\hline SMPSH vs. SMP & $*$ & NS & NS & NS & NS & NS \\
\hline SMPSH vs. F & NS & NS & NS & NS & NS & NS \\
\hline
\end{tabular}

${ }^{2}$ Values are means of 20 plants 27 days after sowing.

Ns $, *, * *$ Nonsignificant or significant at $P=0.05$ or 0.01 , respectively.

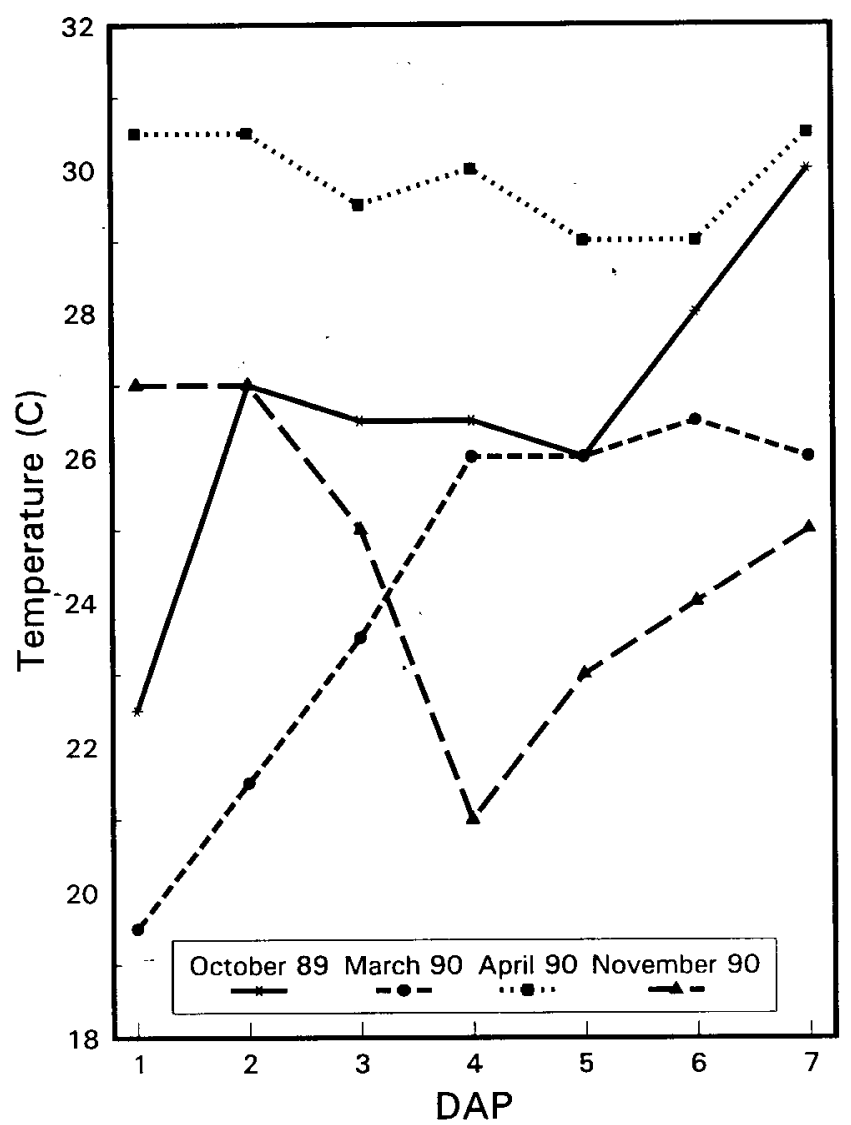

Fig. 1. Average daily soil temperature $(5 \mathrm{~cm}$ deep) for first 7 days after planting (DAP) in Fall 1989, Spring 1990, and Fall 1990 field experiments.

weight, $135-175 \mathrm{~g}$ ) of CNS-711. In HSII, SMPSH treatment significantly improved emergence percentage, ERI, and dry weight of the seedlings compared to nontreated seeds (Table 2). The SMPSH and fungicide treatments produced the highest and fastest emergence and were not significantly different from each other.

Similar to Fall 1989 trials, CNS-711 had more rapid emergence and higher emergence and seedling vigor than HSII in both Spring 1990 sowings (Tables 3 and 4). The SMPSH treatment significantly improved the emergence rate compared to nontreated seeds in both cultivars at both plantings (March and April). The SMPSH and fungicide treatments both increased final emergence and ERI of HSII compared to the other treatments. Under more stressful conditions (higher soil temperature) in April (Fig. 1), the SMPSH treatment also significantly enhanced HSII seedling dry weight over the control and the rate of emergence compared to SNIP treatment alone (Table 4). There were significant differences in yield among treatments in Mar. and Apr. 1990 trials (data not shown), where the final marketable yields were directly related to the final stand. Under cooler conditions of Nov. 1990 (Fig. 1), HSII seeds treated by SMPSH emerged more rapidly and had significantly higher final emergence and dry weight compared to the other treated and nontreated seeds (Table 5). Significantly higher ERI was also shown in CNS-711 seeds primed via SMPSH.

The SMP presowing treatment provides ideal conditions to deliver other products, such as biocontrol agents, to the seed (Harman and Taylor, 1988). SH has been used successfully as a seed disinfectant in $s u$ sweet corn to control Fusarium moniliforme (Anderegg and Guthrie, 1981). The SH and SMP treatments alone were not effective in cold test and field experiments. The addition of SH to the SMP treatment significantly enhanced seed germination and emergence compared to seeds only disinfected with SH or primed alone. Our results indicated that SMP is an excellent delivery system to include $\mathrm{SH}$ as a seed disinfectant.

Greater differences in seed and seedling performance between the nontreated seeds and primed seeds via SMPSH were measured under high (April sowing) or low soil temperature (cold test and Fall 1990). Rapid imbibition, increased seed leakage, and pathogen growth and development may contribute to rapid deterioration of the seeds under these stressful conditions. Lower imbibitional rate and seed leakage had been observed in primed than in control sweet corn seeds (Parera and Cantliffe, 1991). The disinfectant treatment of SH added after partial seed hydration in the SMP process may have contributed to a more effective control of seed-borne pathogen growth and development. The fungicide combination treatment was also effective in increasing germination in the laboratory and field stand in supersweet corn (Cantliffe and Bieniek, 1988; Parera and Cant- 
Table 5. Effect of seed treatments on ERI, emergence percentage, and dry weight (DW) of two sh2 sweet com cultivars in a field experiment planted 8 Nov. 1990 at Gainesville, Fla.

\begin{tabular}{|c|c|c|c|c|c|c|}
\hline \multirow[b]{3}{*}{ Seed treatment } & \multicolumn{6}{|c|}{ Cultivar } \\
\hline & \multicolumn{3}{|c|}{ HSII } & \multicolumn{3}{|c|}{ CNS-711 } \\
\hline & ERI & $\begin{array}{c}\text { Emergence } \\
(\%)\end{array}$ & $\begin{array}{l}\mathrm{DW}^{2} \\
(\mathrm{mg})\end{array}$ & ERI & $\begin{array}{c}\text { Emergence } \\
(\%)\end{array}$ & $\begin{array}{l}\mathrm{DW} \\
(\mathrm{mg})\end{array}$ \\
\hline SMPSH & 167 & 84 & 85 & 178 & 85 & 83 \\
\hline SMP & 67 & 45 & 24 & 167 & 79 & 87 \\
\hline SH & 25 & 19 & 25 & 160 & 82 & 65 \\
\hline Fungicide (F) & 116 & 76 & 42 & 179 & 89 & 86 \\
\hline Control (C) & 26 & 19 & 16 & 136 & 81 & 57 \\
\hline \multicolumn{7}{|c|}{ Orthogonal contrast } \\
\hline SMPSH vs. C & $* *$ & $* *$ & $* *$ & $* *$ & NS & NS \\
\hline SMP vs. SH & $* *$ & $* *$ & NS & NS & NS & NS \\
\hline SMPSH vs. SMP & $* *$ & $* *$ & $* *$ & NS & NS & NS \\
\hline SMPSH vs. F & $* *$ & $*$ & $* *$ & NS & NS & NS \\
\hline
\end{tabular}

${ }^{2}$ Values are means of 20 plants 22 days after sowing.

Ns, ***Nonsignificant or significant at $P=0.0 .5$ or 0.01 , respectively.

liffe, 1990). However, it was necessary to combine four fungicides to achieve the same germination rate and field emergence reached with the SMPSH treatment.

From the laboratory and field results presented, SMPSH improved seed germination, emergence rate, final field stand, and seedling vigor in CNS-711 and HSII sh2 sweet corn cultivars compared with nontreated seeds, especially when $s h 2$ cultivars have inherently poor seed quality and under stressful conditions. The treatment may be a practical replacement for fungicide seed treatments on $s h 2$ sweet corn cultivars. The response of this treatment to a large range of environmental conditions and cultivars needs to be investigated.

\section{Literature Cited}

Anderegg, J. and J.W. Guthrie. 1981. Seedborne Fusarium moniliforme and seedling infection in hybrid sweet corn. Phytopathology 71:1196-1198.

Bennett, M.A. and L. Waters. 1987. Germination and emergence of high-sugar sweet corn is improved by presowing hydration of seed. HortScience 22:236-238.

Berger, R.D. and E.A. Wolf. 1974. Control of seedborne and soilborne mycoses of 'Florida Sweet' corn by seed treatment. Plant Dis. Rptr. 58:922-923.

Bodsworth, S. and J.D. Bewley. 1981. Osmotic priming of seeds of crops species with polyethylene glycol as a mean of enhancing early and synchronous germination at cool temperatures. Can. J. Bet. 59:672-676.

Bradford, K.J. 1986. Manipulation of seed water relations via osmotic priming to improve germination under stress conditions. HortScience 21:1105-1112.

Cantliffe, D.J. 1981. Priming of lettuce seed for early and uniform conditions of environmental stress. Acts Hort. 122:29-46.

Cantliffe, D.J. and M. Bieniek. 1988. Improving plant stands of super sweet corn by seed treatment. Proc. Fla. State Hort. Soc. 101:372376.

Cantliffe, D. J., E.A. Wolf, and J.M. White. 1975. Improved germination and plant stand of 'Florida Sweet' corn by seed treatment. Proc. Fla. State Hort. Soc. 88:170-173.

Harman, G.E. and A.G. Taylor. 1988. Improved seedling performance by integration of biological control agents at favorable $\mathrm{pH}$ levels with solid matrix priming. Phytopathology 78:520-525.

Harman, G. E., A.G. Taylor, and T.E. Stasz. 1989. Combining effective strains of Trichoderma harzianum and solid matrix priming to improve biological seed treatments. Plant Dis. 73:631-637.

Khan, A. A., N.H. Peck, and C. Samimy. 1980. Seed osmoconditioning: Physiological and biochemical changes. Israel J. Bot. 29: 133144.

Kubik, K. K., J.A. Eastin, J.D. Eastin, and K.M. Eskridge. 1989. Solid matrix priming of tomato and pepper. Proc. Intl. Conf. Stand Establishment Hort. Crops. p. 86-96.

Parera, C.A. and D.J. Cantliffe. 1990. Improved stand establishment of shrunken-2 sweet corn by seed treatments. Proc. Fla. State Hort. Soc. 103:153-158.

Parera C.A. and D.J. Cantliffe. 1991. Improved germination and modified imbibition of sbunken-2 sweet corn by seed disinfection and solid matrix priming. J. Amer. Soc. Hort. Sci. 116:942-945.

Schoen, J.F. and M.M. Kulik. 1977. Towel germination and field emergence of treated and nontreated sweet corn seeds infested with Fusarium moniliforme. J. Seed Technol. 2:48-51.

Shmueli, M. and D. Goldberg. 1971. Emergence, early growth, and salinity of five vegetable crops germinated by sprinkle and trickle irrigation in an arid zone. HortScience 6:563-565.

Styer, R.C. and D.J. Cantliffe. 1983. Relationship between environment during seed development and seed vigor of two endosperm mutants of corn. J. Amer. Soc. Hort. Sci. 108:717-720.

U.S. Dept. of Agriculture. 1954. United States standards for grade of green corn. U.S. Dept. Agr. Agr. Marketing Serv., Washington, D.C. 